\title{
Studies on the performance of different genotypes of cauliflower grown in plains and higher altitude of Kerala
}

\author{
K. Elavarasan ${ }^{1, *}$, P. B. Pushpalatha ${ }^{1}$, P. Jocob John ${ }^{1}$, K. B. Sheela ${ }^{1}$, \\ C. Narayanankutty ${ }^{2}$ \\ ${ }^{1}$ Department of Processing Technology (Horticulture), College of Horticulture, \\ Kerala Agriculture University, Vallanikara, Thrissur - 680656, Kerala, India \\ ${ }^{2}$ Department of Horticulture, Agriculture Research Station, Mannuthy, Thrissur, Kerala, India \\ *E-mail address: princekau@gmail.com
}

\begin{abstract}
Cauliflower is grown in all the agro climatic zones of India, accounting for an area of 3.9 lakh hectares with production of 73.4 lakh tones. Hence, studies are to be undertaken to identify genotype and analyze the physical characteristics among the cultivated genotypes (Namdhari Seeds $60 \mathrm{~N}$, Namdhari Seeds 133, Pusa Meghna and Basant) grown under hills and plains of Kerala, India. In this study, significant differences were observed in yield of cauliflower which ranged from $21-26.4 \mathrm{~kg}$ $/ 16 \mathrm{~m}^{2}$ in hills and $0.78-1.43 \mathrm{~kg} / 16 \mathrm{~m}^{2}$ in plains. Among the cauliflower genotypes, NS 133 was found to be the best for hilly region in early yield and yield attributes. The cauliflower genotype NS 133 exhibited better performance in hills in terms of high curd yield $\left(26.4 \mathrm{Kg} / 16 \mathrm{~m}^{2}\right)$, curd weight $(800 \mathrm{~g})$ and curd height $(13.93 \mathrm{~cm})$. In general, harvest maturity was delayed by $39-45$ days in the plains as compared to higher altitudes. The cauliflower genotypes which exhibited superior performance in hills and plains were selected for further sensory evaluation studies. In this study cauliflower genotype NS $60 \mathrm{~N}$ recorded superior organoleptic qualities when grown in plains than hilly region. However in the case of genotype NS 133, the differences in sensory qualities between produce from hills and plains were not significant.
\end{abstract}

Keywords: Cauliflower; Genotypes; Performance; Yield attributes; Sensory quality

\section{INTRODUCTION}

Cauliflower (Brassica oleracea var. botrytis L., $2 \mathrm{n}=2 \mathrm{x}=18$ ) of the family Brassicaceae or Cruciferacea is used as a white edible portion i.e. curd. It is one of the most important Cole crops grown under temperate to tropical climate conditions for its curd in more than ninety countries throughout the world. It is a rich source of minerals like phosphorus, potassium, calcium, sodium and iron. It is grown in all the agro climatic zones of India, accounting for an area of 3.9 lakh hectares with production of 73.4 lakh tones and it's grown throughout the country but is more popular in southern states where it is available all the year (NHB, 2012). In northern India also, the cauliflower availability period has been considerably extended with the development of tropical varieties or hybrids. Cauliflower is a thermo sensitive crop. It loses its flavour in dry warm weather condition. According to 
Chadha (2002) the growth of the cauliflower genotypes is arrested, when temperature rises above $25^{\circ} \mathrm{C}$ even in higher altitudes. Similarly, Singh (2007) reported that the optimum temperatures for curd formation are $15-22{ }^{\circ} \mathrm{C}$ with an average maximum $25^{\circ} \mathrm{C}$ and minimum of $8^{\circ} \mathrm{C}$.

High temperature during curd maturity period promotes defective curds and deteriorate quality of curds. Chubey et al. (2006), reported that climate play a significant influence on expression of characters. Mckeown et al. (2004) reported that yield of cauliflower decreased with warmer average temperature and number of days was found to above $30{ }^{\circ} \mathrm{C}$ with fewer days of precipitation.

Higher temperatures probably will increase heat related quality disorders and possibly reduce vitamin content. In recent past the cultivation of cauliflower is being extended to the plains from higher altitude of Kerala. As the genotype interacts considerably with the environment in which they are grown and identification of genotype which performs well in the plains will be immense value to the farmer. Hence, studies are to be undertaken to identify genotypes with appreciable yield and yield attributes of produce and organoleptic quality.

\section{MATERIAL AND METHODS}

Experimental material comprised of four genotypes namely NS 133, NS 60N, Pusa Meghna and Basant. Cauliflower genotypes was simultaneously raised in the plains of Agriculture Research Station, Department of Horticulture, Mannuthy and hills of Orange and Vegetable farm, Nelliyampathy during the winter season of 2009 to 2011 . Each genotype was planted in a plot having $8.0 \times 2.0 \mathrm{~m}$ area in randomized block design with five replications.

There were 44 plants in each plot planted at $60 \times 60 \mathrm{~cm}$ spacing. All the standard package of practices and plant protection measures were timely adopted to raise the crop successfully. Ten randomly selected plants from each replication were utilized for recording observations viz., days to maturity, curd height $(\mathrm{cm})$, curd weight $(\mathrm{kg})$, curd solidity, curd yield (t/ha) and sensory attributes of selected genotypes (Hedonic scale).

\section{RESULT AND DISCUSSION}

Cauliflower maturity index was recorded by attaining the maximum curd size and firmness. The cauliflower genotype, NS 133 matured early in hilly region whereas in the plains it took longer time (39-45 days) to reach harvest maturity (Fig. 1). According to Booij (1990) about $55 \%$ of the variance in duration of the harvest period of a crop could be explained by the combined effect of variation in duration of the curd initiation period and in temperature during curd growth.

The NS 133 recorded the highest curd yield $\left(26.4 \mathrm{Kg} / 16 \mathrm{~m}^{2}\right.$ plot) in hilly region (Fig. 2). In plains, NS $60 \mathrm{~N}$ recorded the highest curd yield $\left(1.43 \mathrm{~kg} / 16 \mathrm{~m}^{2}\right.$ plot $)$ among the different genotypes. According to Meena et al. (2010) yield and its component characters are polygenic in nature, hence influenced by the environmental factors. 


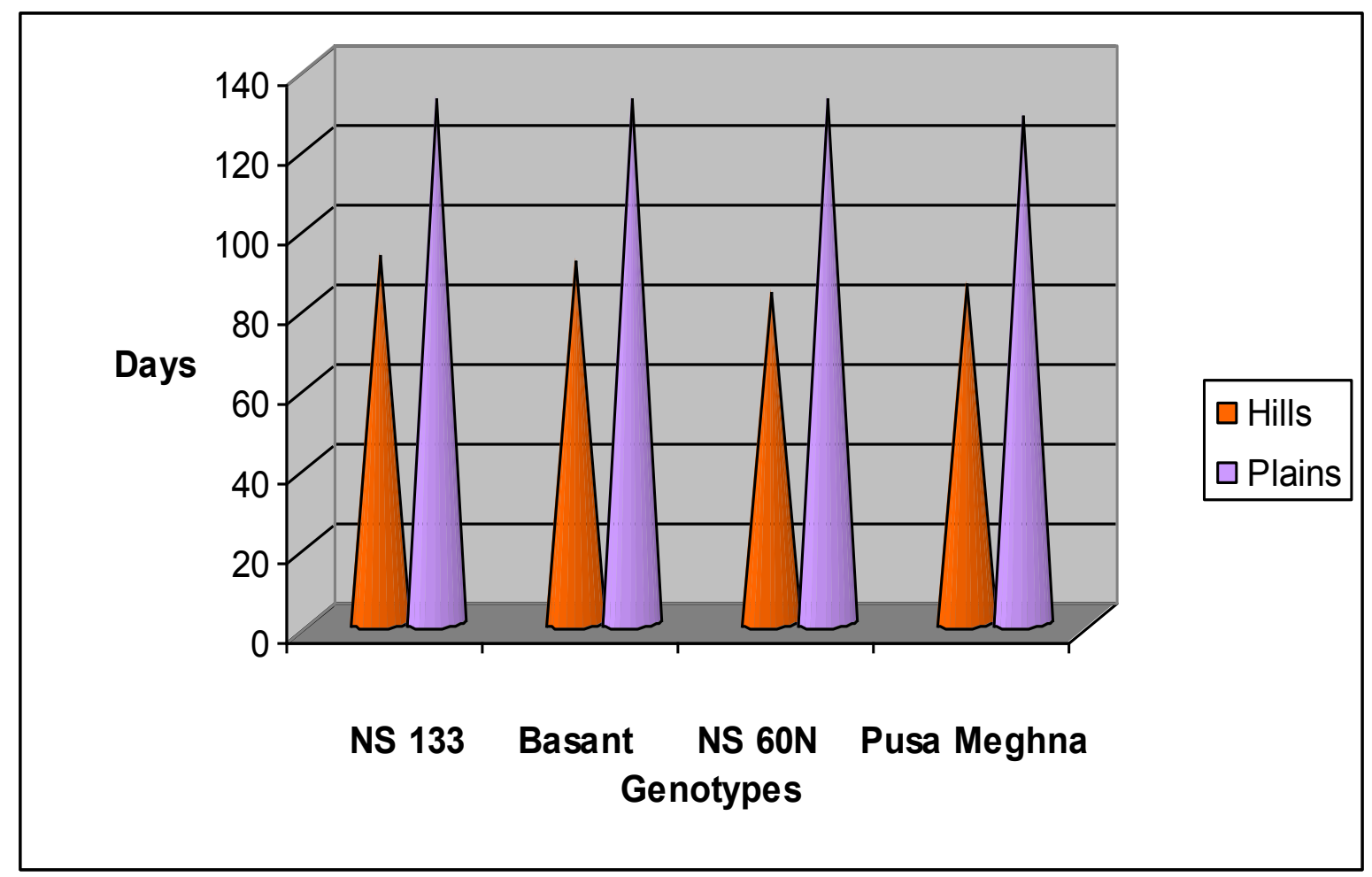

Fig. 1. Days to maturity.

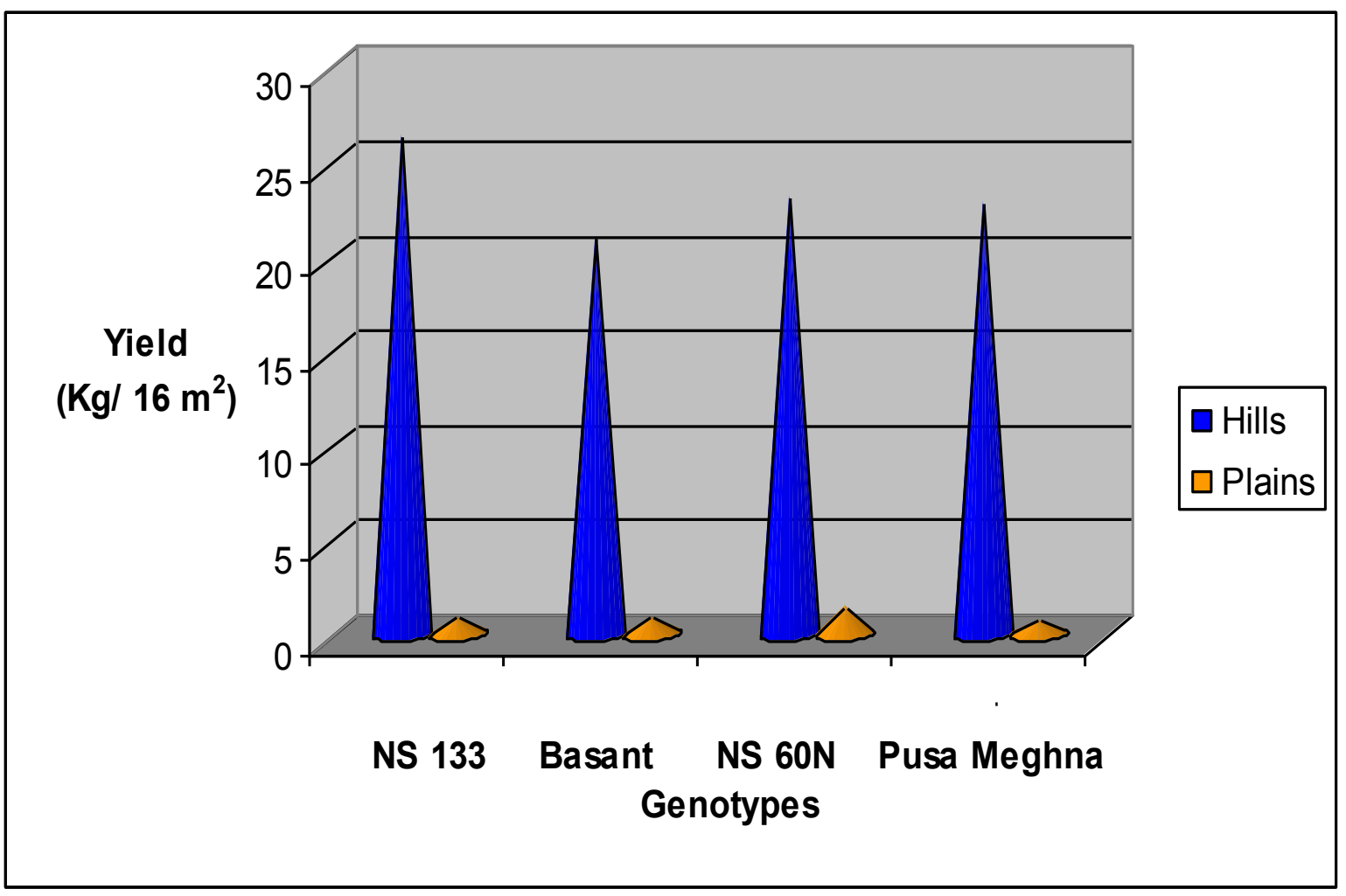

Fig. 2. Curd yield. 
The genotypes, Basant, NS 133 and Pusa Meghna did not perform well in the plains which is evident from the low yield recorded ranges from $0.78-0.87 \mathrm{Kg} / 16 \mathrm{~m}^{2}$.

Sharma et al. (2006) reported that among the traits, harvest index, curd size index, net curd weight and curd breadth should be given emphasis while selection of genotype for high curd yields in cauliflower. The results of the present study pointed out that temperature is an important factor contributing to curd yield. The critical duration of high temperature exposure ranged from $27.5^{\circ} \mathrm{C}$ and $37.4^{\circ} \mathrm{C}$ and caused limited growth in cauliflower. The recorded curd weight and curd height of NS 133 was $800(\mathrm{~g})$ and $13.93(\mathrm{~cm})$ respectively in hilly region. NS $60 \mathrm{~N}$ recorded highest curd weight $(82 \mathrm{~g})$ and curd height $(8.15 \mathrm{~cm})$ compared to all the other genotypes raised in plains (Fig. 3 and 4). This may due to lack of efficient utilization of limiting factors like nutrients, light, air and moisture (Semuli, 2005). According to Choudhury et al. (2004) increase in curd size and curd height may be due to high translocation of metabolites or plant nutrients in cauliflower. In case of density is a measure of solidity and is most frequently employed as an indicator of maturity. In hilly region, all the cauliflower genotypes produced firm and uniform curds but in plains curds were thicker and non-uniform, which may due to genetically hardwired, photoperiod or other environmental factors were involved (Wurr et al., 1996).

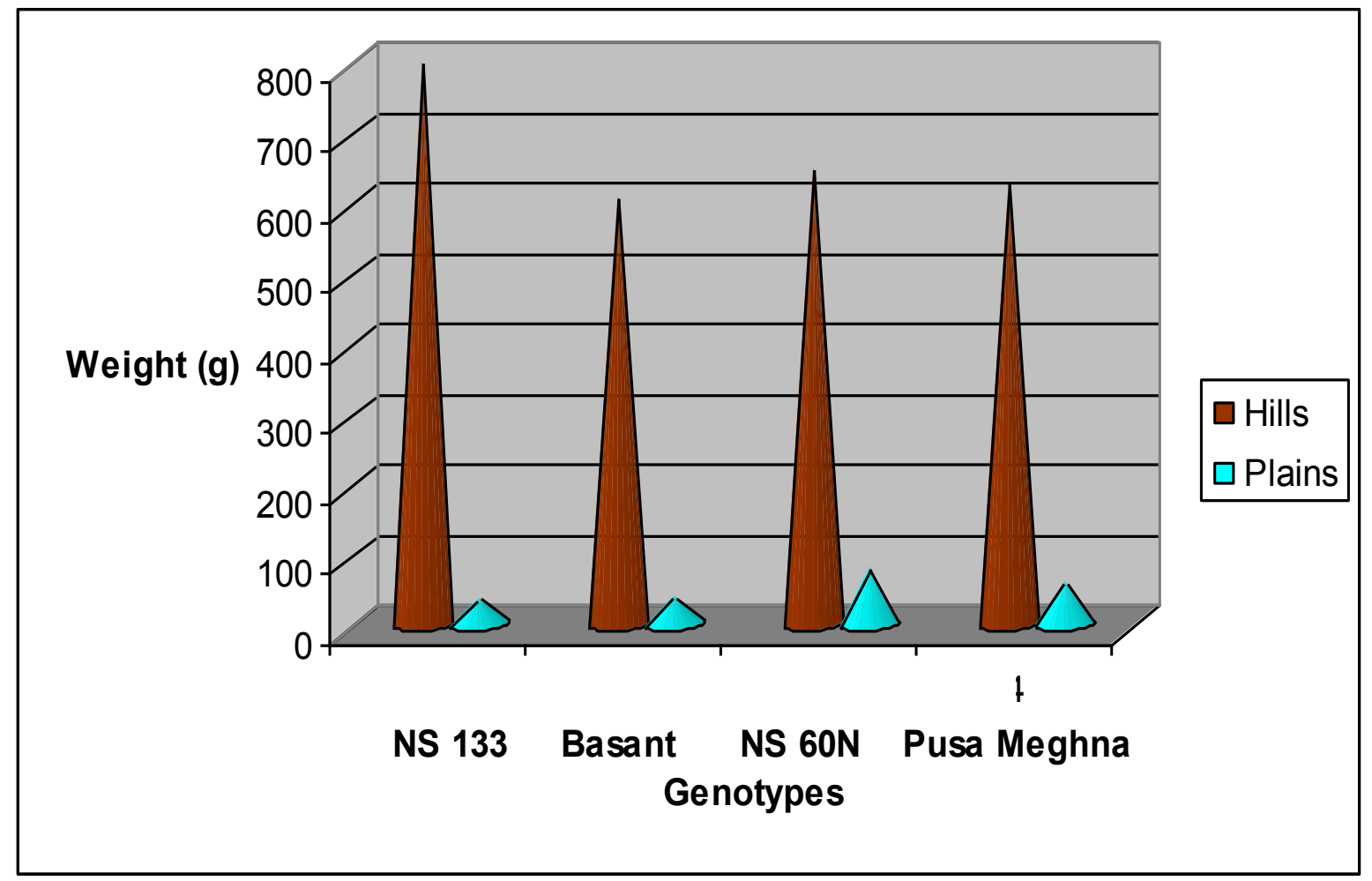

Fig. 3. Curd weight.

Among the cauliflower genotypes which exhibited superior performance in hills and plains were selected for further sensory evaluation studies. In this studies separately analysed sensory evaluation for before storage (fresh produce) and after one week of storage. In general, before storage produce giving good organoleptic quality than in after one week of storage. 


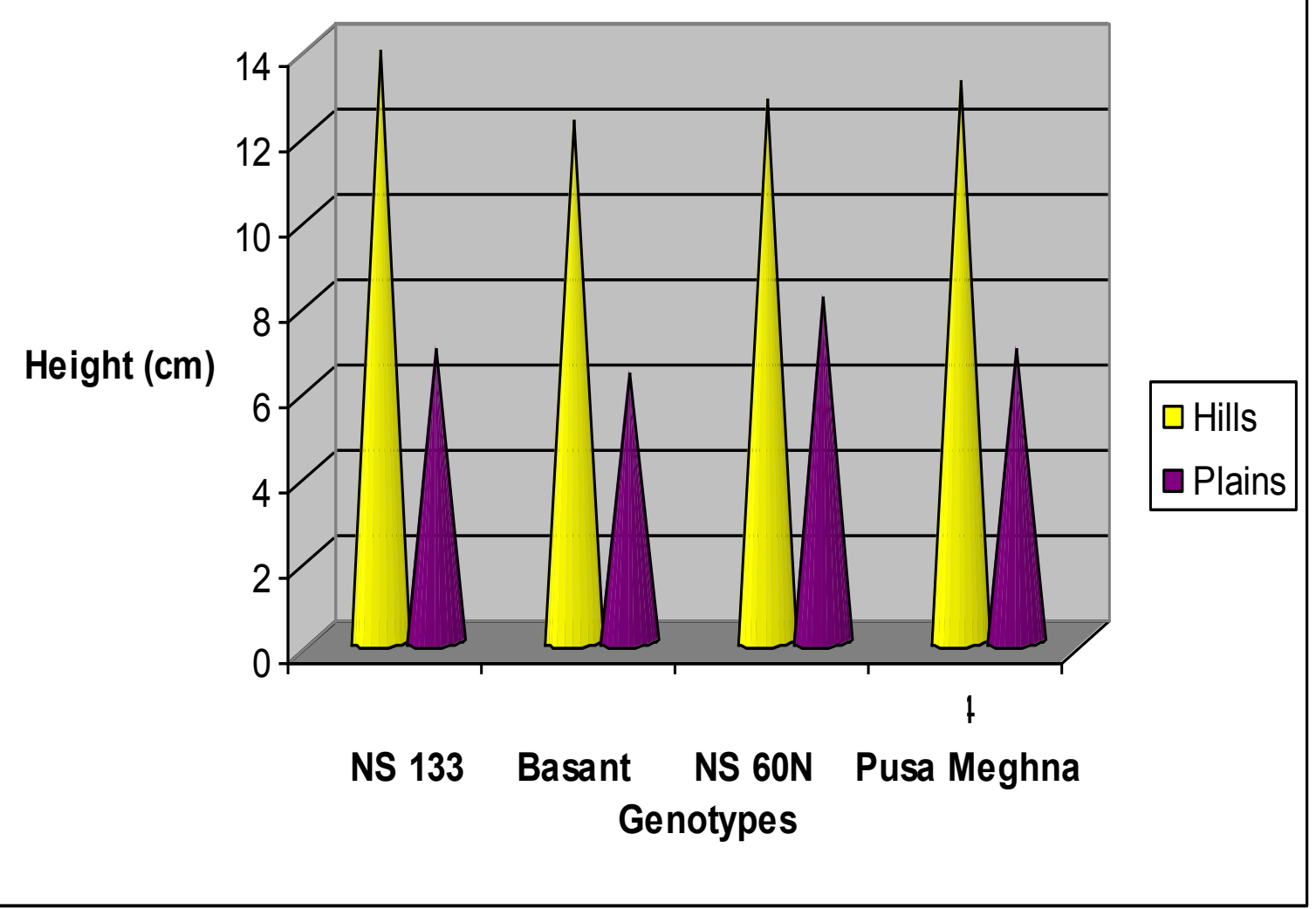

Fig. 4. Curd height.

Higher mean score of colour (4.3), taste (3.8), flavour (4.6) and texture (3.6) was recorded for the genotype NS $60 \mathrm{~N}$ from the plains. Yano et al. (1990) reported that plains grown genotypes contain more sugar content than hills because of high concentrations of sulfur containing glucosinolates, which influence the perception of sweetness (Table 1).

The variety, plant spacing and planting date affect a wide range of organic compounds associated with cauliflower flavour.

Highest mean score for texture was observed in plains of NS $60 \mathrm{~N}$ which may be due to better dry matter and sugar accumulation resulting in better texture in plains as reported by Suojala, 2003. Buike and Alsina (2003) suggested that calcium is one of the most important nutrients responsible for improving the sensory quality of cauliflower texture.

Among the cauliflower genotype NS $60 \mathrm{~N}$ recorded superior organoleptic qualities (colour, taste, flavour, texture and overall acceptability) when grown in plains than in hilly region (Table 2). 
Table 1. Mean scores for organoleptic qualities of cauliflower, genotype NS 133.

\begin{tabular}{|c|c|c|c|c|c|c|c|c|c|c|c|c|c|c|c|}
\hline \multirow[b]{2}{*}{.} & \multicolumn{3}{|c|}{ Colour } & \multicolumn{3}{|c|}{ Taste } & \multicolumn{3}{|c|}{ Flavour } & \multicolumn{3}{|c|}{ Texture } & \multicolumn{3}{|c|}{$\begin{array}{c}\text { Overall } \\
\text { acceptability }\end{array}$} \\
\hline & 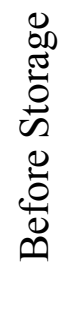 & 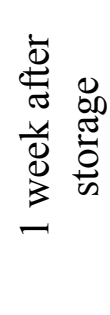 & 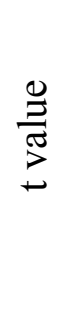 & 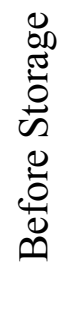 & 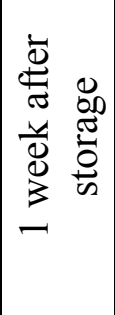 & $\begin{array}{l}\stackrel{\varrho}{\Xi} \\
\stackrel{\Xi}{\Xi}\end{array}$ & 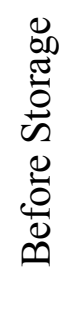 & 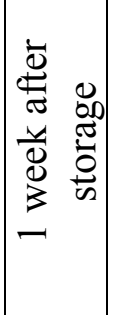 & $\frac{\stackrel{0}{\Xi}}{\stackrel{\pi}{ \pm}}$ & 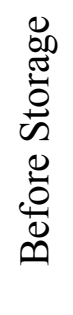 & 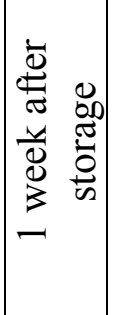 & $\begin{array}{l}\stackrel{0}{3} \\
\stackrel{\pi}{ \pm}\end{array}$ & 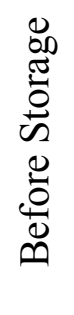 & 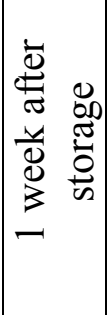 & 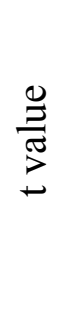 \\
\hline 急 & 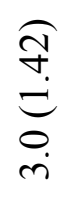 & 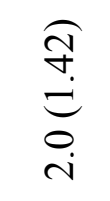 & 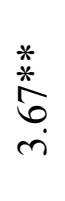 & 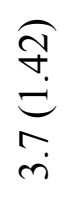 & 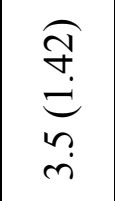 & $\begin{array}{l}\stackrel{*}{*} \\
\stackrel{\text { d }}{i}\end{array}$ & 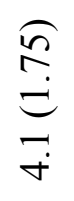 & 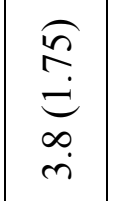 & $\begin{array}{l}\frac{.}{*} \\
\stackrel{6}{6} \\
\dot{n}\end{array}$ & $\underset{-\infty}{\stackrel{n}{\infty}}$ & $\underset{\stackrel{\infty}{n}}{\stackrel{\infty}{=}}$ & + & 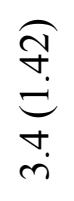 & 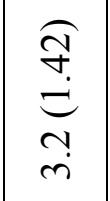 & $\stackrel{*}{\stackrel{*}{*}} \underset{\sim}{\stackrel{n}{i}}$ \\
\hline$\frac{\mathscr{a}}{\stackrel{\Xi}{2}}$ & 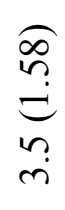 & 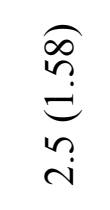 & $\stackrel{\text { * }}{\stackrel{\text { C. }}{\mathrm{I}}}$ & $\underset{\substack{\infty \\
\oplus}}{\stackrel{\infty}{\sim}}$ & 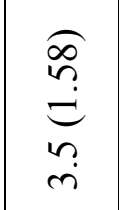 & $\frac{\stackrel{*}{*}}{\stackrel{i}{i}}$ & $\underset{\substack{\tilde{n} \\
\stackrel{n}{c}}}{\stackrel{n}{n}}$ & 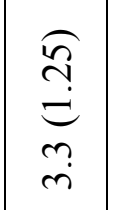 & $\begin{array}{l}\stackrel{*}{*} \\
\stackrel{*}{+}\end{array}$ & $\begin{array}{l}\stackrel{\tilde{n}}{+} \\
\stackrel{0}{r} \\
\dot{n}\end{array}$ & 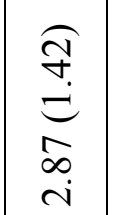 & 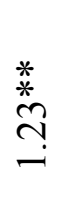 & $\underset{\substack{\infty \\
\stackrel{\infty}{n}}}{\stackrel{\infty}{\infty}}$ & $\begin{array}{l}\stackrel{\infty}{\infty} \\
\stackrel{n}{\sim} \\
\stackrel{n}{n}\end{array}$ & $\tilde{Z}$ \\
\hline 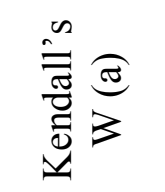 & $\stackrel{0}{0}$ & $\stackrel{m}{0}$ & & $\stackrel{3}{0}$ & $\stackrel{8}{\circ}$ & & $\tilde{0}$ & 0 & & 0 & 0 & & $\stackrel{3}{0}$ & $\stackrel{m}{0}$ & \\
\hline 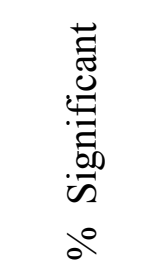 & $\stackrel{n}{2}$ & : & & $\stackrel{n}{6}$ & ?̊ & & $\begin{array}{l}\infty \\
0 \\
0\end{array}$ & oे & & - & - & & $\stackrel{n}{6}$ & : & \\
\hline
\end{tabular}

Values in parenthesis are mean rank scores

$* *=$ Significant at $1 \%$ level

$+\quad=$ ' $\mathrm{t}$ ' test not performed as all observation were equal

$\mathrm{NS}=$ Non significant 
Table 2. Mean scores for organoleptic qualities of cauliflower, genotype NS 60N.

\begin{tabular}{|c|c|c|c|c|c|c|c|c|c|c|c|c|c|c|c|}
\hline \multirow{2}{*}{ 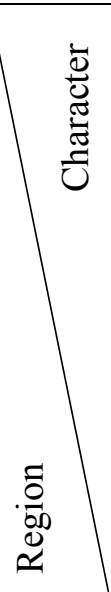 } & \multicolumn{3}{|c|}{ Colour } & \multicolumn{3}{|c|}{ Taste } & \multicolumn{3}{|c|}{ Flavour } & \multicolumn{3}{|c|}{ Texture } & \multicolumn{3}{|c|}{$\begin{array}{c}\text { Overall } \\
\text { acceptability }\end{array}$} \\
\hline & 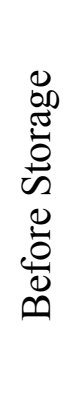 & 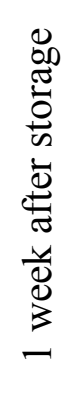 & $\frac{\mathscr{0}}{\stackrel{3}{7}}$ & 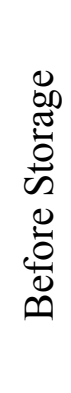 & 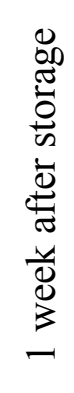 & $\frac{\mathscr{g}}{\stackrel{乛}{\tilde{J}}}$ & 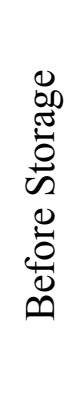 & 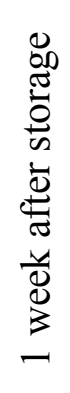 & $\begin{array}{l}\stackrel{0}{\Xi} \\
\stackrel{\pi}{ \pm}\end{array}$ & 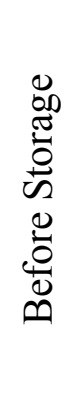 & 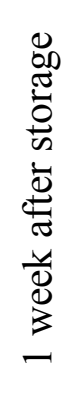 & 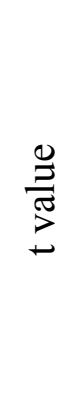 & 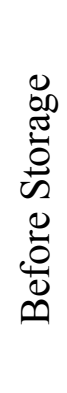 & 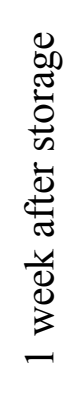 & 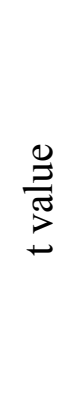 \\
\hline$\stackrel{0}{:}$ & 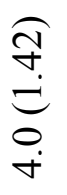 & 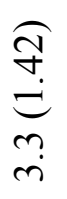 & $\begin{array}{l}* \\
* \\
\stackrel{*}{\infty} \\
-\end{array}$ & 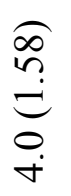 & $\begin{array}{l}\stackrel{\infty}{n} \\
\stackrel{n}{=} \\
\underset{n}{m}\end{array}$ & 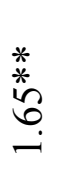 & 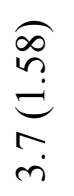 & 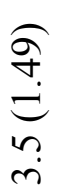 & $\stackrel{*}{*}$ & $\underset{n}{\stackrel{\overbrace{}}{y}}$ & 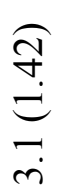 & $\begin{array}{l}\stackrel{*}{*} \\
\stackrel{*}{\sigma} \\
\text { i }\end{array}$ & 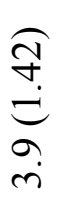 & 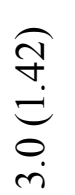 & $\begin{array}{l}\stackrel{*}{*} \\
\stackrel{*}{\Xi}\end{array}$ \\
\hline 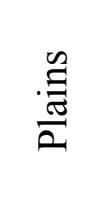 & 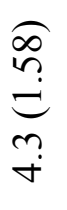 & 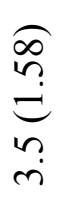 & $\frac{*}{\stackrel{*}{*}} \stackrel{0}{\sigma}$ & 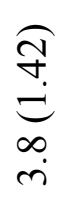 & 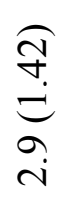 & $\begin{array}{l}\stackrel{*}{*} \\
\stackrel{*}{=}\end{array}$ & 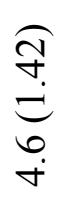 & 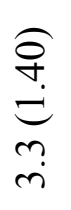 & $\begin{array}{l}\stackrel{*}{*} \\
\stackrel{*}{6} \\
\dot{r}\end{array}$ & 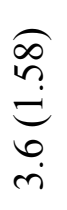 & 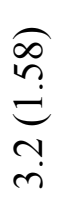 & $\begin{array}{l}\stackrel{*}{*} \\
\stackrel{*}{*} \\
\dot{+}\end{array}$ & 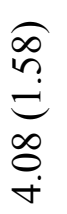 & $\begin{array}{l}\underset{\infty}{n} \\
\stackrel{=}{=} \\
\underset{m}{m}\end{array}$ & $\begin{array}{l}* \\
\stackrel{*}{*} \\
\underset{0}{0}\end{array}$ \\
\hline 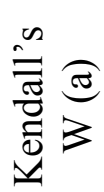 & $\stackrel{n}{0}$ & $\hat{0}$ & & $\stackrel{0}{0}$ & 光 & & $\frac{\infty}{0}$ & $\stackrel{0}{0}$ & & $\stackrel{n}{0}$ & 仓̊. & & $\hat{0}$ & $\stackrel{0}{0}$ & \\
\hline 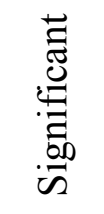 & $\stackrel{n}{n}$ & $\stackrel{0}{n}$ & & $\stackrel{n}{6}$ & $\stackrel{\infty}{\infty}$ & & $\tilde{n}$ & $\vec{n}$ & & $\stackrel{0}{n}$ & $\begin{array}{l}0 \\
0 \\
0\end{array}$ & & $\begin{array}{l}n \\
\mathfrak{0} \\
0\end{array}$ & $\begin{array}{l}n \\
0 \\
0\end{array}$ & \\
\hline$\partial^{0}$ & & & & & & & & & & & & & & & \\
\hline
\end{tabular}

Values in parenthesis are mean rank scores

** = Significant at $1 \%$ level

$+\quad=$ ' $\mathrm{t}$ ' test not performed as all observation were equal

NS $=$ Non significant 


\section{CONCLUSION}

From above finding it may be concluded that genotype NS $60 \mathrm{~N}$ giving good physical and organoleptic quality in plains of Kerala, whereas NS 133 showing better performance in higher altitudes of Kerala.

\section{ACKNOWLEDGEMENT}

The Authors express their thanks to Indian Council of Agriculture Research for providing JRF for this study.

\section{References}

[1] R. Booij, Journal of Horticulture Science and Biotechnology 65 (1990) 167-176.

[2] I. Buike, I. Alsina, Acta Horticulture 599 (2003) 725-730.

[3] K. L. Chadha, Hand Book of Horticulture, ICAR Publisher, 2002, New Delhi, p. 364.

[4] M. R. Choudhury, A. Saikia, N. C. Talukdar, Biovedic 15 (2004) 83-87.

[5] A. W. McKeown, J. Warland, M. R Mcdonald, C. M. Hutchinson, Acta Horticulture 638 (2004) 241-248.

[6] M. L Meena, R. B. Ram, R. Lata, S. R. Sharma, International Journal of Science and Nature 1 (2010) 27-30.

[7] NHB [National Horticulture Board]. 2012. NHB home page [online]. Available: http://nhb.gov.in/area\%20_production.html [01 March 2012].

[8] K. L. H. Semuli, Nitrogen requirements for cabbage (Brassica oleracea capitata) transplants and crop response to spacing and nitrogen top-dressing. M. Sc. Thesis, University of Pretoria, 2005, South Africa, 57 p.

[9] A. Sharma, S. Sharma, S. Pathak, S. Sood, Vegetables Science 33 (2006) 82-84.

[10] D. K. Singh, International book distributing co, 2007, Lucknow, 159 p.

[11] T. Suojala, Journal of Horticulture Science and Biotechnology 78 (2003) 821-827.

[12] D. C. E. Wurr, J. R. Fellows, K. Phelps, Journal of Horticulture Science 71 (1996) 273-286.

[13] M. Yano, R. Saijo, W. Sugawara, H. Ohta, Nippon shokuhin kogyo gakkaishi 7 (1990) 478-483. 